\title{
Nursing diagnoses in trauma victims with fatal outcomes in the emergency scenario ${ }^{1}$
}

\author{
Ana Maria Calil Sallum² \\ Jair Lício Ferreira dos Santos ${ }^{3}$ \\ Fernão Dias de Lima ${ }^{4}$
}

\begin{abstract}
The objective of this study was to identify and analyze the nursing diagnoses that constitute risk factors for death in trauma victims in the first 6 hours post-event. This is a cross-sectional, descriptive and exploratory study using quantitative analysis. A total of 406 patients were evaluated over six months of data collection in a tertiary hospital in the municipality of São Paulo, according to an instrument created for this purpose. Of the total, $44(10.7 \%)$ suffered death. Multivariate analysis indicated the nursing diagnoses ineffective respiratory pattern, impaired spontaneous ventilation, risk of bleeding and risk of ineffective gastrointestinal tissue perfusion as risk factors for death and ineffective airway clearance, impaired comfort, and acute pain as protective factors, data that can direct health teams for different interventionist actions faced with the complexity of the trauma.
\end{abstract}

Descriptors: Nursing Diagnosis; Emergency Medical Services; Nursing Records; Wounds and Injuries; Death.

\footnotetext{
${ }^{1}$ Paper extracted from Post-doctoral degree Dissertation "Identificação de diagnósticos de enfermagem em pacientes de trauma em unidade de emergência" presented to Escola de Enfermagem, Universidade de São Paulo, SP, Brazil. Supported by Fundação de Amparo à Pesquisa do Estado de São Paulo (FAPESP), process \# 09/51308-0.

2 RN, Post-doctoral student in Nursing, Escola de Enfermagem, Universidade de São Paulo, SP, Brazil. E-mail: easallum.fnr@terra.com.br.

${ }^{3}$ Physicist, Ph.D. in Public Health, Full Professor, Faculdade de Medicina de Ribeirão Preto, Universidade de São Paulo, SP, Brazil. E-mail: jalifesa@usp.br.

${ }^{4}$ IT Analyst, Faculdade de Saúde Pública, Universidade de São Paulo, SP, Brazil. E-mail: feddlima@usp.br.
}

Corresponding Author: Ana Maria Calil Sallum Av. Dr Enéas de Carvalho Aguiar, 419 Bairro: Cerqueira César CEP: 05403-000, São Paulo, SP, Brasil E-mail: easallum.fnr@terra.com.br 


\section{Diagnósticos de enfermagem em vítimas fatais decorrentes de trauma no cenário da emergência}

O objetivo deste estudo foi identificar e analisar diagnósticos de enfermagem que constituem fatores de risco para óbito, em vítimas de trauma, nas primeiras 6 horas após o evento. Trata-se de estudo transversal, descritivo e exploratório, com análise quantitativa. Avaliaram-se 406 pacientes durante seis meses de coleta em um hospital terciário do município de São Paulo, segundo instrumento criado para essa finalidade. Do total, 44 (10,7\%) evoluíram para óbito. Análise multivariada apontou os diagnósticos de enfermagem padrão respiratório ineficaz, ventilação espontânea prejudicada, risco de sangramento e risco de perfusão tissular gastrintestinal ineficaz como fatores de risco para óbito e desobstrução ineficaz de vias aéreas, conforto prejudicado e dor aguda como fatores de proteção, dados que podem direcionar as equipes de saúde para ações intervencionistas diferenciadas frente à complexidade do trauma.

Descritores: Diagnóstico de Enfermagem; Serviços Médicos de Emergência; Registros de Enfermagem; Ferimentos e Lesões; Morte.

\section{Diagnósticos de enfermería en víctimas fatales provenientes de trauma en el escenario de la atención de emergencia}

El objetivo de este estudio fue identificar y analizar diagnósticos de enfermería que constituyen factores de riesgo para muerte en víctimas de trauma en las primeras 6 horas después del evento. Se trata de un estudio transversal, descriptivo y exploratorio con análisis cuantitativo. Se evaluó 406 pacientes durante seis meses de recolección en un hospital terciario del Municipio de São Paulo, según instrumento creado para esa finalidad. Del total, 44 (10,7\%) evolucionaron para muerte. El análisis multivariado apuntó los diagnósticos de enfermería: patrón respiratorio ineficaz, ventilación espontánea perjudicada, riesgo de sangramiento y riesgo de perfusión tisular gastrointestinal ineficaz, como factores de riesgo para muerte; la desobstrucción ineficaz de vías aéreas, confort perjudicado y dolor agudo como factores de protección, datos que pueden orientar a los equipos de salud para realizar acciones intervencionistas diferenciadas frente a la complejidad del trauma.

Descriptores: Diagnóstico de enfermería; Registros de Enfermería; Servicios Médicos de Emergencia; Heridas y Traumatismos; Muerte.

\section{Introduction}

External causes have been a serious Public Health problem in our country for over four decades, since they are responsible for a substantial part of morbidity, mortality, disability and sequelae, as well as considerable socioeconomic cost ${ }^{(1)}$. An example of these statistics refers to road traffic accidents, which, in the year 2007, amounted to 383,371 with the number of casualties of 513,510 , which projected a mean of 1,406 accidents/ day and 1,369 victims/day (1.30 victims per accident), which equates to $15.5 \%$ of all hospitalizations for injuries and demonstrates the impact of these injuries ${ }^{(2)}$.
The recognition of this problem as the epidemic of the twentieth century, led to specialists in the area of trauma developing care protocols for these victims in the pre-hospital and intra-hospital scenario, and to the training of thousands of professionals who militate in these areas, in order to decrease the mortality and reduce the sequelae ${ }^{(3)}$. The standardization of the care to trauma victims has been carried out by Health Institutions in Brazil for over twenty years. However, the need to individualize the care is a reality experienced by all the professionals who participate 
in these consultations, due to their different forms of presentation, severity and complexity and accordingly the use of nursing diagnoses seemed an interesting and useful route for acting in the emergency scenario(4). In pursuing of this route and after an extensive literature review on the theme, a knowledge gap was identified in the area of nursing diagnoses related to fatal victims resulting from trauma in our environment and in the international scenario, which seems a paradox due to the importance of the nurse in this care.

Nursing diagnoses are clinical judgments regarding the responses of the individual, of the family or of the community to health problems, real or potential vital processes ${ }^{(5-6)}$. The nursing diagnoses provide the basis for the selection of nursing interventions to achieve results for which the nurse is responsible, especially for serious victims and those with greater complexity ${ }^{(7-8)}$. Studying the causes and the consequences of a disease is essential in order to establish a diagnosis and to contribute to the adoption of preventive, control, care and education measures ${ }^{(4)}$. In this sense, knowing the incidence of the nursing diagnoses with these victims and those most frequent in fatal victims is consistent with the national profile of morbidity and mortality and provides support for the performance with greater security and the stimulation for this study ${ }^{(5)}$. Considering the responsibility of nurses for serious and critical patients and the complexity of the trauma, the Brazilian epidemiological framework, the formulation of nursing diagnoses based on the identification of signs and symptoms, the speed in the clinical reasoning and the specifics of the care for these victims, the current study was developed with the aim of identifying and analyzing the nursing diagnoses that constitute risk factors for death in trauma victims.

\section{Method}

This is a cross-sectional, descriptive and exploratory study using quantitative analysis. The first step consisted of the construction and trial of a data collection instrument for achieving the proposed aim. From a list made by the researcher and then judged by seven nurses, specialists in nursing diagnoses and trauma for over 15 years, the final definition was arrived at of an instrument with 43 nursing diagnoses and numerous defining characteristics and risk factors associated with the six hours post-trauma period ${ }^{(9)}$. The literature related to nursing diagnoses, the validation of data collection instruments, the evaluation of the trauma patient and the evaluation of the critical patient in an emergency situation defined the model (construction) of the data collection instrument(10-13). The NANDA2009-11 was used as a guide for selecting the diagnoses(5). After this step, the data collection instrument was applied with victims of external causes that were encountered in the first six hours post-event, aged 18 years or over, attended at the Hospital of the data collection (tertiary, in the municipality of São Paulo), for a six month period, from $1^{\text {st }}$ December, 2009 to $31^{\text {st }}$ May, 2010. The confirmation of the time of the event was given by the pre-hospital services/military police/family members/ friends or the patients themselves (in the cases of the Glasgow Coma Scale=15); in the case of doubt, the patient was excluded from the study.

A schedule of shifts was established in order to allow a random collection, in the morning (7:00 to 13:00), afternoon (13:00 to 19:00) and night (19:00 to 7:00) periods. The collection began after approval by the Ethics Committee of the Hospital of the Study, under protocol number 0843/09. The patients and/or family members were consulted regarding the agreement to participate in the study and a copy of the terms of Free Prior Informed Consent remained with them. After the collection of the data, $20 \%$ of the sample was validated by a specialist in nursing diagnoses, achieving $98 \%$ of concordance with the data collected by the researcher.

All the independent variables (nursing diagnoses) are of the dichotomous type, with $0=$ yes $1=$ no, meaning whether the patient received a determined diagnosis or not. The dependent variable death is also binomial, with 0 indicating no occurrence and 1 the occurrence of a death event. The number of events per variable is close to the value of 10 proposed by some specialists ${ }^{(14)}$. However, the variables were selected in order to avoid or reduce the possible effects of collinearity. To this end, the Variance Inflation Factor (VIF) was calculated according to the usual recommendation of not having a VIF mean greater than $5^{(14-15)}$. Additionally, the correlations were studied of variables with VIF $>5$ to substitute them with some of their possible combinations. To this end, we proceeded to calculate the Variance Inflation Factor (VIF), and there was the usual recommendation of not having a VIF mean greater than $5^{(14-15)}$.

Once the variables were selected, the ranking of their relative importance was established by means of multivariate analysis with a logistic regression(15). The model adopted was that of stepwise regression for backwards elimination. The model starts with the presence of all the variables, and, at each step, the 
variable that's contribution does not present significant alteration to the fixed $p$ level is eliminated. As the set of diagnosis can present correlations between some of them, and as it can be desirable to maintain them in the model for clinical reasons, a $p$ value of 0.20 was chosen. In the final result those variables with odds ratios that had $p$-values less than $5 \%$ were considered significant.

\section{Results}

Following the established criteria, after 6 months of collection, a total sample of 406 trauma victims was obtained. Of these, 44 (10.7\%) suffered death.

Table 1 - Frequency of the Nursing Diagnoses (ND) in fatal victims (44). São Paulo, Brasil, 2010

\begin{tabular}{|c|c|c|c|c|}
\hline \multirow{2}{*}{$\begin{array}{c}\text { Variables } \\
\text { ND }\end{array}$} & \multicolumn{2}{|c|}{ Frequency } & \multicolumn{2}{|c|}{ Deaths } \\
\hline & $\mathbf{n}$ & $\%$ & $\mathbf{n}$ & $\%$ \\
\hline Risk for infection & 42 & 95.4 & 44 & 100 \\
\hline Risk for aspiration & 38 & 86.4 & 44 & 100 \\
\hline Impaired skin integrity & 37 & 84.0 & 44 & 100 \\
\hline Ineffective respiratory pattern & 36 & 82.8 & 44 & 100 \\
\hline Risk for bleeding & 35 & 79.5 & 44 & 100 \\
\hline Impaired spontaneous ventilation & 34 & 77.3 & 44 & 100 \\
\hline Impaired tissue integrity & 30 & 68.2 & 44 & 100 \\
\hline Risk for ineffective cerebral perfusion & 29 & 66.0 & 44 & 100 \\
\hline Risk for shock & 28 & 63.6 & 44 & 100 \\
\hline Decreased cardiac output & 26 & 59.1 & 44 & 100 \\
\hline Impaired gas exchange & 23 & 52.3 & 44 & 100 \\
\hline $\begin{array}{l}\text { Decreased intracranial adaptive } \\
\text { capacity }\end{array}$ & 23 & 52.3 & 44 & 100 \\
\hline Hypothermia & 21 & 47.8 & 44 & 100 \\
\hline Risk for fluid imbalance & 21 & 47.8 & 44 & 100 \\
\hline $\begin{array}{l}\text { Risk for imbalance in body } \\
\text { temperature }\end{array}$ & 16 & 36.4 & 44 & 100 \\
\hline Decreased cardiac perfusion & 15 & 34.1 & 44 & 100 \\
\hline Ineffective clearance of airway & 14 & 31.8 & 44 & 100 \\
\hline Risk for ineffective renal perfusion & 14 & 31.8 & 44 & 100 \\
\hline $\begin{array}{l}\text { Risk for ineffective gastrointestinal } \\
\text { perfusion }\end{array}$ & 14 & 31.8 & 44 & 100 \\
\hline Risk for neurovascular dysfunction & 13 & 29.5 & 44 & 100 \\
\hline Ineffective peripheral tissue perfusion & 12 & 27.3 & 44 & 100 \\
\hline Deficient fluid volume & 12 & 27.3 & 44 & 100 \\
\hline Acute confusion & 10 & 23.0 & 44 & 100 \\
\hline Impaired oral mucosa & 9 & 20.4 & 44 & 100 \\
\hline Acute pain & 8 & 18.2 & 44 & 100 \\
\hline Risk for electrolyte imbalance & 8 & 18.2 & 44 & 100 \\
\hline Impaired transfer ability & 7 & 15.9 & 44 & 100 \\
\hline Impaired verbal communication & 7 & 15.9 & 44 & 100 \\
\hline Ineffective thermoregulation & 7 & 15.9 & 44 & 100 \\
\hline Impaired dentition & 7 & 15.9 & 44 & 100 \\
\hline Impaired physical mobility & 6 & 13.6 & 44 & 100 \\
\hline Disturbed kinesthetic sensory & 5 & 11.4 & 44 & 100 \\
\hline
\end{tabular}

(continue...)
Table 1 - (continuation)

\begin{tabular}{|c|c|c|c|c|}
\hline \multirow{2}{*}{$\begin{array}{c}\text { Variables } \\
\text { ND }\end{array}$} & \multicolumn{2}{|c|}{ Frequency } & \multicolumn{2}{|c|}{ Deaths } \\
\hline & $\mathbf{n}$ & $\%$ & $\mathbf{n}$ & $\%$ \\
\hline Disturbed visual sensory perception & 5 & 11.4 & 44 & 100 \\
\hline Impaired memory & 4 & 9.1 & 44 & 100 \\
\hline Anxiety & 4 & 9.1 & 44 & 100 \\
\hline Risk for acute confusion & 3 & 6.8 & 44 & 100 \\
\hline Fear & 2 & 4.5 & 44 & 100 \\
\hline Nausea & 2 & 4.5 & 44 & 100 \\
\hline Weigh & 1 & 2.7 & 44 & 100 \\
\hline Moral distress & 1 & 2.7 & 44 & 100 \\
\hline Knowledge deficit & 1 & 2.7 & 44 & 100 \\
\hline Risk for disturbed maternal-fetal dyad & 0 & 0 & 44 & 100 \\
\hline
\end{tabular}

Table 1 shows all the NDs considered. It can be observed that the first 12 nursing diagnoses listed occurred for more than $50 \%$ of the population that suffered death.

\section{Selection of the variables}

The mean VIF value for all the variables was 4.11 and did not, therefore, present limitations for the purposes of this work. Variables with a VIF greater than 5 are shown in Table 2

Table 2 - Variance inflation factor values of the variables (Nursing Diagnoses) with VIF>5. São Paulo, Brasil, 2010

\begin{tabular}{lcc}
\hline \multicolumn{1}{c}{ Nursing Diagnosis } & VIF & 1/VIF \\
\hline Disturbed kinesthetic sensory perception, & 12.72 & 0.078616 \\
Ineffective respiratory pattern & 11.48 & 0.087109 \\
Impaired spontaneous ventilation & 11.20 & 0.089261 \\
Disturbed visual sensory perception & 11.03 & 0.090621 \\
Impaired comfort & 8.53 & 0.117291 \\
Acute pain & 8.26 & 0.121109 \\
Risk of infection & 7.26 & 0.137696 \\
Impaired skin integrity & 5.92 & 0.168780 \\
Impaired verbal communication & 5.20 & 0.192169 \\
\hline
\end{tabular}

The study of the correlation between the variables is shown in Table 3.

Diagnosis 3 - Ineffective respiratory pattern; Diagnosis 5 - Impaired spontaneous ventilation; Diagnosis 20 - Impaired verbal communication; Diagnosis 21 - Impaired comfort; Diagnosis 22 Impaired visual sensory perception; Diagnosis 23 impaired kinesthetic sensory perception; Diagnosis 25 - Acute pain; Diagnosis 27 - Risk for infection; Diagnosis 29 - Impaired skin integrity. 
Table 3 - Spearman correlation and P values of the variables with VIF>5. São Paulo, Brasil, 2010

\begin{tabular}{|c|c|c|c|c|c|c|c|c|}
\hline ND 29 & ND 03 & ND 05 & ND 20 & ND 21 & ND 22 & ND 23 & ND 25 & ND 27 \\
\hline ND 03 & 1.0000 & & & & & & & \\
\hline \multirow[t]{2}{*}{ ND 05} & 0.9250 & 1.0000 & & & & & & \\
\hline & 0.0000 & & & & & & & \\
\hline \multirow[t]{2}{*}{ ND 20} & 0.0710 & 0.0710 & 1.0000 & & & & & \\
\hline & 0.1526 & 0.1526 & & & & & & \\
\hline \multirow[t]{2}{*}{ ND 21} & -0.5399 & -0.5399 & -0.1521 & 1.0000 & & & & \\
\hline & 0.0000 & 0.0000 & 0.0021 & & & & & \\
\hline \multirow[t]{2}{*}{ ND 22} & 0.0293 & 0.0293 & 0.8124 & -0.1169 & 1.0000 & & & \\
\hline & 0.5559 & 0.5559 & 0.0000 & 0.0183 & & & & \\
\hline \multirow[t]{2}{*}{ ND 23} & 0.0216 & 0.0391 & 0.8337 & -0.1055 & 0.9381 & 1.0000 & & \\
\hline & 0.6637 & 0.4313 & 0.0000 & 0.0333 & 0.0000 & & & \\
\hline \multirow[t]{2}{*}{ ND 25} & -0.5387 & -0.5522 & -0.2019 & 0.7397 & -0.1485 & -0.1530 & 1.0000 & \\
\hline & 0.0000 & 0.0000 & 0.0000 & 0.0000 & 0.0027 & 0.0027 & & \\
\hline \multirow[t]{2}{*}{ ND 27} & 0.2162 & 0.2162 & 0.1226 & -0.1712 & 0.1276 & 0.1317 & -0.1919 & 1.0000 \\
\hline & 0.0000 & 0.0000 & 0.0133 & 0.0005 & 0.0100 & 0.0078 & 0.0001 & \\
\hline \multirow[t]{2}{*}{ ND 29} & 0.1840 & 0.1840 & 0.0776 & -0.1339 & 0.0374 & 0.0444 & -0.1528 & 0.3508 \\
\hline & 0.0002 & 0.0002 & 0.1180 & 0.0068 & 0.4512 & 0.3713 & 0.0020 & 0.0000 \\
\hline
\end{tabular}

Table 3 shows: High positive correlation of Diagnosis 3 with Diagnosis 5; High positive correlations of Diagnosis 20 with Diagnosis 22 and Diagnosis 23. High positive correlation between Diagnosis 21: and 25; Medium negative correlations of the Diagnoses 21 and 25 with Diagnoses 3 and 5 and medium correlation between Diagnoses 27 and 29 (positive). As a result, substituting the variables with some combinations suggested by the correlations was studied. Thus, it was determined: Diagnosis 03 or 05 (d03or05) Diagnosis 20 or 22 or 23 (d20or22or23) Diagnosis 21 or 25 (d21or25). The new calculation of the VIF values showed a decrease in the mean to 3.03 and only three variables with VIF greater than 5, a very acceptable condition for proceeding with the multivariate analysis. The stepwise logistic regression, with retro elimination presented the following results:

Table 4 - Results of Logistic Regression for the dependent variable death. São Paulo, Brasil, 2010

\begin{tabular}{|c|c|c|c|c|c|c|}
\hline \multirow{2}{*}{$\begin{array}{l}\text { Death } \\
\text { ND } 01\end{array}$} & \multirow{2}{*}{$\begin{array}{c}\text { Odds Ratio } \\
0.3285781\end{array}$} & \multirow{2}{*}{$\begin{array}{c}\text { Standard error } \\
0.19528\end{array}$} & \multirow{2}{*}{$\frac{\mathbf{z}}{-1.87}$} & \multirow{2}{*}{$\begin{array}{l}<\mathrm{P}|\mathrm{z}| \\
0.061\end{array}$} & \multicolumn{2}{|c|}{ Confidence interval $95 \%$} \\
\hline & & & & & 0.1025071 & 1.05323 \\
\hline ND 25 & 0.158875 & 0.0987111 & -2.96 & $0.003^{*}$ & 0.0470103 & 0.5369305 \\
\hline ND 24 & 0.3871859 & 0.241215 & -1.52 & 0.128 & 0.1141891 & 1.312847 \\
\hline ND 29 & 0.2566981 & 0.1875099 & -1.86 & 0.063 & 0.0613263 & 1.074481 \\
\hline ND 07 & 2.346404 & 1.404797 & 1.42 & 0.154 & 0.725749 & 7.586109 \\
\hline ND 08 & 3.410735 & 1.93457 & 2.16 & $0.031^{*}$ & 1.122138 & 10.36692 \\
\hline ND 26 & 2.170742 & 1.266798 & 1.33 & 0.184 & 0.6916165 & 6.813197 \\
\hline ND 43 & 2.513987 & 1.593679 & 1.45 & 0.146 & 0.7257133 & 8.70885 \\
\hline ND 11 & 3.272508 & 2.18017 & 1.78 & $0.075^{\star}$ & 0.8867552 & 12.07696 \\
\hline ND03or05 & 4.347399 & 2.801834 & 2.28 & $0.023^{*}$ & 1.229257 & 15.37504 \\
\hline
\end{tabular}

* Significant at $5 \%$.

No. observations $=406$

$\operatorname{chi}^{2}(11)=130.46$

Prob > $\mathrm{chi}^{2}=0.0000$

Pseudo $\mathrm{R}^{2}=0.4683$

Log likelihood $=-74.067916$ 
It was observed that the diagnoses $3,5,8$ and 11 are risk factors for death.

\section{Discussion}

The analysis of Table 1 shows that of the 12 NDs encountered in at least $50.0 \%$ of the fatalities, five of them relate directly to the oxygen supply and the consequences of inadequate ventilation: Risk of aspiration, Ineffective respiratory pattern, Impaired spontaneous ventilation, Risk of ineffective cerebral perfusion and Impaired gas exchange. Another finding of extreme clinical importance for the personnel who work in the emergency department refers to the four NDs relating to fluid replacement and control of hemorrhage represented by risk for shock, risk for bleeding, decreased cardiac output and risk for ineffective cerebral perfusion (since this relates to the quantity of circulating volume). Among the NDs that appeared for at least $50.0 \%$ of the study population, those related to neurological evaluation and patient exposure are also prominent, represented by: risk for ineffective cerebral perfusion/ diminished intracranial adaptive capacity and impaired skin integrity/impaired tissue integrity, respectively.

A study conducted in our environment identified factors associated with survival of trauma victims in the pre-hospital period and one of the main findings showed a positive statistically significant association of survival with basic and advanced respiratory procedures. Conversely, the same study identified that the patients who underwent advanced respiratory procedures, thoracic compressions, volume replacement and patients with abdominal injury of Injury Severity Score (ISS) $\geq 25$ had an increased risk of death within the first 48 hours post-trauma(16). These findings are closely related with the NDs identified in this study and with the two great enemies to be overcome in the trauma-related emergency (hypovolemic shock/ bleeding + alterations in oxygen supply) and their repercussions and consequences for the body, as well as the high incidence of mortality ${ }^{(17)}$. In the above study, 175 victims were analyzed and of these, 63 (30.6\%) suffered death, with $50.8 \%$ up to 6 hours post-event, which shows the importance of developing studies that analyze the post-trauma period. Regarding protective measures, the category of volume replacement was the only one considered effective ${ }^{(16)}$.

The risk of bleeding in the patients with greater severity and the importance of volemic replacement in trauma victims was encountered in other studies, as well as related interventionist measures ${ }^{(18-19)}$. The risk for shock represented by hypotension/hypovolemia/ hypoxia/increased or decreased heart rate and the trauma itself is a common situation among victims of external causes, especially those with abdominal/ thoracic injuries and with traumatic amputations of lower limbs and exposed fractures ${ }^{(16-17)}$.

Since trauma is a complex event, the variety of injuries and their severity are a daily challenge for the teams in emergency scenarios. Furthermore, considering that a single ND would not be sufficient to define an outcome, it was considered appropriate to evaluate a group of NDs related to the outcome of death, that is, are there more NDs related to the death or the survival outcome? The proposed statistical analyses considered the issue and the main findings are shown as follows. The interpretation of the data shows as risk factors for death, a close relationship between the ND number 3 - ineffective respiratory pattern and 5 impaired spontaneous ventilation (analyzed conjointly or separately). It can be observed that these NDs are related to the first two stages of initial care for multiple trauma patients, i.e. they establish relationships with airway clearance and adequate oxygen supply. Another way to interpret the findings could reveal the pathophysiological alterations resulting from the inadequate oxygen supply to the body that can result from numerous causes, and the alterations in perfusion in various organs and tissues, as a result of hypoxia or hypoxemia, lead to the outcome of death(3,17). This finding reveals the importance of the measures of ventilatory support, training, continuing education of health teams in the intra and extra hospital scenarios and in the search for exemplary related practices.

The Diagnoses 8 - risk for bleeding and 11 - risk for ineffective gastrointestinal tissue perfusion show the impact of volemic loss for victims of trauma and the importance of its control during the care ${ }^{(17)}$. The identification of these nursing diagnoses provides the nurse with the possibility of working directly on this issue as protective measures related to hypovolemic shock. The injuries in the abdominal, thoracic and pelvic areas represent constant concern, since they are largely responsible for hypovolemic shock, although in varying degrees and, even with diagnostic imaging, not always being apparent ${ }^{(20)}$. The above statement concurs with the definition of the theme that highlights the Nursing diagnoses with a clinical judgment as the responses of the individual, of the family or of the community to health problems/real or potential vital processes ${ }^{(5)}$. The 
nursing diagnoses provide the basis for the selection of nursing interventions to achieve results for which the nurse is responsible ${ }^{(8,18)}$. An interesting finding of this study refers to the protective factors identified, related here to survival. The high positive correlation found between the protective factors ND 21 - impaired comfort and ND 25 - acute pain, can be explained by the high frequency of patients reporting feeling uncomfortable because of acute pain post-trauma, a fact that was only possible to identify in hemodynamically stable and conscious patients ${ }^{(4)}$.

The literature highlights the problem of underevaluation and under-treatment of acute pain in the emergency department, which in our environment is approximately $70.0 \%{ }^{(4)}$. The priorities of resuscitation and stabilization of the condition in the care of multiple trauma patients are unquestionable, however, it is crucial to question other aspects which favor the quality of the care, such as the inclusion of the evaluation and management of the pain, the use of objective instruments for the evaluation of the pain intensity, and the use of protocols, among others ${ }^{(4)}$. The mean negative correlation between the nursing diagnoses 3 and 5 and the nursing diagnoses 21 and 25 can be comprehended by the difficulty of evaluating the painful phenomenon and the comfort in patients with alteration or difficulty in the respiratory pattern ${ }^{(4)}$.

In relation to ND 20 - impaired verbal communication with ND 22 - disturbed sensory perception and ND 23 - disturbed kinesthetic sensory perception, the high positive correlation can be comprehended by the high number of patients that present impaired communication as a defining characteristic. This finding may direct the teams to create interventionist tools and models regarding this health problem, which is so common in facial trauma, for example. The relationships established between ND 27 - risk of infection and ND 29 - impaired skin integrity is explained by the high number of trauma patients who present the need for invasive procedures, rupture of the skin surface/invasion of body structures and rupture of the skin surface, above all by the high incidence of injuries to the external surface and limbs(20).

Another important aspect that merits consideration in this study concerns the multivariate analysis (statistical model adopted) which focuses on comprehending the scenario as a whole and not just the strength of one or another variable(15). In a univariate analysis, the outcome of death or survival can be evaluated analyzing each ND individually in comparison to each outcome. Ex: when analyzing nursing diagnosis 1 (obstruction of the airways) in a table with death, a strong relationship with this outcome will appear. It is then said that this diagnosis and death are related, but this may not be true, given the relationship of this ND with all the other variables. Multivariate analysis takes this into account when producing results.

As previously mentioned, trauma is a complex event and should be viewed in a broad way, aiming for a more adequate comprehension of the phenomenon. The need for a constant search for tools that suggest ways to improve the quality of our actions is the duty of every health professional involved with their practice and the NDs propose, in our view, a possible route for the development of clinical and critical reasoning in conjunction with the trauma victims. Performing a cross-sectional study can be viewed as a limitation of the research. However, it is hoped that these findings may be questioned, tested, replicated and refined by other researchers and that the sum of this knowledge is reflected in improved care for a significant portion of our population that is affected daily by this serious public health problem - trauma due to external causes.

\section{Conclusion}

The multivariate analysis through logical regression indicated the NDs ineffective respiratory pattern, impaired spontaneous ventilation, risk of ineffective gastrointestinal tissue perfusion and risk of bleeding as risk factors for death and the NDs ineffective airway clearance, impaired comfort, and acute pain as protective factors, data that can direct the health teams in different qualitative interventionist measures and in the planning of distinct actions faced with the complexity of the trauma. Based on these data, specific actions of nursing competence can be discussed and proposals should be formulated related to the domains activity/rest in which the 4 NDs are inserted, in a scenario where the time between life and death is tenuous.

\section{References}

1. Ministério da Saúde (BR). DATASUS [Internet]. Brasília: Ministério da Saúde. Óbitos por causas externas - Brasil. [acesso 10 jul. 2010]. Disponível em: http:// tabnet.datasus.gov.br/cgi/tabcgi.exe?sim/cnv/extuf.def 2. Mello Jorge MHP, Koizumi MS. Acidentes de trânsito no Brasil: um atlas de sua distribuição. São Paulo: ABRAMET; 2007.

3. American College of Surgeons - ACS. Committe on Trauma. Advanced trauma Life Support Manual. 9ed. Des Plaines, Illinois; 2010. 
4. Calil AM, Pimenta CAM. A importância da avaliação e padronização analgésica em serviços de emergência. Acta Paul Enferm. 2010;65(1):132-8.

5. NANDA International. Diagnósticos de enfermagem da NANDA: definições e classificação 2009-2011. Porto Alegre: Atmed; 2009.

6. Goyatá SLT, Rossi LA, Dalri MCB. Diagnósticos de enfermagem de familiares de pacientes adultos queimados no período próximo à alta hospitalar. Rev. Latino-Am. Enfermagem. 2006;14(1):102-9.

7. Galdeano LE, Rossi LA. Construção e validação de instrumento de coleta de dados para o período perioperatório de cirurgia cardíaca. Rev. Latino-Am. Enfermagem. 2002;10(6):800-4.

8. Carvalho EC. Relações entre a coleta de dados, diagnóstico e prescrição de enfermagem a pacientes adultos de uma UTI. Rev. Latino-Am. Enfermagem. 2008;16(4):700-6.

9. Sallum Calil AM, Sousa RMC. Construção de um instrumento para identificar diagnósticos de enfermagem relacionados às vítimas de trauma. Acta Paulista. 2011. No prelo

10. Garlet ER, Lima MADS, Santos JLG, Marques GQ. Organização do trabalho de uma equipe de saúde no atendimento ao usuário em situações de urgência e emergência. Texto Contexto Enferm. 2009;18(2):266-72. 11. Macfarlane C, Benn CA. Evaluation of emergency medical system: a classification to assist in determination of indicators. Emerg Med J. 2003;20(2):188-91.

12. Müller-Staub M, Lavin MA, Needham I, Achterberg T. Nursing diagnoses, interventions and outcomesapplication and impact on nursing practice: systematic review. J Adv Nurs. 2006;56(6):514-31.

13. Meislin $\mathrm{H}$. Fatal injury: characterístics and prevention of deaths in the scene. J Trauma. 1999;46(3):457-61.

14. Peduzzi P, Concato J, Kemper E, Holford TR, Feinstein AR. A simulation study of the number of events per variable in logistic regression analysis. J Clin Epidemiol. 1996; 49(12):1373-9.

15. Rabe-Hesketh S, Everitt B. A Handbook of Statistical Analyses Using Stata. 3.ed. Boca Raton (FL): Chapman \& Hall; 2004.

16. Malvestio MAA, Sousa RMC. Sobrevivência após acidente de trânsito: impacto das variáveis clínicas préhospitalares. Rev Saúde Publica. 2008;42(6):639-47.

17. Sallum EA, Birolini D, Coimbra R, Poli F, Rocha e Silva M., Calil AM. Blood loss and transcapillary refill in uncontrolled treated hemorrhage. Clinics. 2010;69(1):187-95.
18. Cyrillo RMZ. Intervenções de enfermagem para situações de volume de líquidos deficientes: aplicabilidade da NIC no atendimento avançado pré-hospitalar móvel [tese de doutorado]. Ribeirão Preto (SP): Escola de Enfermagem de Ribeirão Preto da Universidade de São Paulo; 2009. 141 p.

19. Cyrillo RMZ. Diagnósticos de enfermagem em vítimas de trauma no atendimento avançado préhospitalar móvel [dissertação de mestrado]. Ribeirão Preto (SP): Escola de Enfermagem de Ribeirão Preto da Universidade de São Paulo; 2005. 112 p.

20. Nogueira LS, Domingues CA. Mapeamento de lesões em vítimas de acidentes de transporte: revisão sistemática da literatura. Rev. Latino-Am. Enfermagem. 2009;17(1):120-5. 